Izvorni članak UDK 1:304(045)

doi: $\underline{10.21464 / f i 36303}$

Primljeno 7. 6. 2016.

\title{
Ivo Džinić
}

Sveučilište J. J. Strossmayera u Osijeku, Odjel za kulturologiju, Trg Svetog Trojstva 3, HR-31000 Osijek idzinic@kulturologija.unios.hr

\section{Utjeha filozofije i Pohvala ludosti: paradigmatski okvir kvalitete življenja}

\begin{abstract}
Sažetak
U pozadini članka stoje dva spisa koja svojom jednostavnošću, ali i dubinom promišljanja, predstavljaju paradigmatski okvir ispravne kulture življenja. Riječ je o Boetijevom (480.525.) spisu Utjeha filozofije $i$ o spisu Erazma Roterdamskoga (1465.-1536.) Pohvala ludosti. Ozbiljnim filozofskim pristupom i intelektualnim naporom Boetije pokazuje da se pravi smisao i vrijednost čovjekova života temelji na odgovornosti prema životu i na njegovoj etičnosti. S druge strane, promišljajući o ludosti, Erazmo na strogo satiričan način dolazi do zaključka da se istinska mudrost sastoji u spoznaji vlastite ograničenosti i opuštenog mirenja s iluzornim karakterom života. U članku se želi pokazati da uravnotežena kombinacija vrijednosnih postulata ovih dvaju spisa predstavlja izvrstan paradigmatski okvir ispravne kvalitete življenja.
\end{abstract}

Ključne riječi

Boetije, Erazmo Roterdamski, Utjeha filozofije, Pohvala ludosti, vrijednosni postulati, kvaliteta življenja.

\section{Uvod}

Zasigurno najpoznatije djelo iz bogate filozofske ostavštine Anicija Manlija Severina Boetija (480.-525.), »posljednjeg Rimljana«, kako ga je u 15. st. okarakterizirao Lorenzo Valla, jest Utjeha filozofije (Consolatio Philosophiae) iz 525. godine. Riječ je o djelu koje je postalo klasikom i koje je sve do 17. stoljeća spadalo u najčitaniji filozofski opus. ${ }^{1}$ Resi ga ozbiljan i strogo filozofski pristup s izraženom oštroumnošću promišljanja o najdubljim tajnama ljudskoga bivovanja, kao i pokušaj razumijevanja pravoga smisla života. Upravo to djelo i vrijednosni postulati koji se iz njega iščitavaju jedan su od žarišta interesa ovoga članka.

Uz Boetijevu Utjehu filozofije u članku se istovremeno u razmatranje uzima i djelo Erazma Roterdamskoga (1465.-1536.) pod nazivom Pohvala ludosti (Stultitiae laus) iz 1511. godine. Kao jedan od najutjecajnijih europskih humanista i »posljednji od velikih latinskih pisaca «, Erazmo u tom djelu na zajedljivo satiričan način piše o ludosti kao skrivenoj riznici života i životne spontanosti, koja nije samo odgovorna za ljudske pogreške nego ljudima tek i pomaže istinski živjeti. Spoznaja vlastite ograničenosti i opušteno mirenje

1

Usp. Birgit Ehrenberg, »Mit dem Philosophen auf der Couch«, Hohe Luft 5 (2014), str. 79-82.
2

Léon-Ernest Halkin, Erazmo i kršćanski humanizam, Kršćanska sadašnjost, Zagreb 2005., str. 118. 
s iluzornim karakterom života vrijednosti su koje zapravo predstavljaju istinsku mudrost.

Na početku se samo po sebi nameće pitanje o tome što povezuje ova dva autora i njihova dva spomenuta spisa da bi ih bilo uopće vrijedno i moguće stavljati u zajednički kontekst. U prvi mah se može činiti da postoji daleko veći broj elemenata prema kojima se razlikuju, kao što su, primjerice, milenijska vremenska distanca, različite povijesne i životne okolnosti, motivi koji su ih potaknuli na pisanje ovdje razmatranih spisa, pa i sam pristup tajni ljudskoga života i detektiranju onoga što mu daje istinski smisao. Međutim, nisu teško uočljive i određene sličnosti, kao što su život na epohalnim prekretnicama i izazovi »novoga«, zauzetost u proučavanju antičkih mislilaca i njihovih djela, istančan osjećaj za etički ispravni život i prezir prema svakom obliku prijetvornosti. Čak i metodološki, oba autora u svojim spisima pokazuju sličnosti, napose u pogledu alegorijskog prikaza glavnih aktera njihovih djela, odnosno prikaza filozofije i ludosti u personificiranom liku žene. U konačnici, može se ustvrditi da se dvojica autora i sadržajno u bitnome podudaraju, napose kada prokazuju krive i lažne vrijednosti, a ističu one prave $i$ istinite koje ljudskom životu tek i daju pravi smisao.

Iako upravo navedeno više nego dovoljno opravdava stavljanje dvojice autora i njihovih spisa u zajednički kontekst, prava je namjera ovoga teksta pokazati kako neki vrijednosni postulati Boetijeve Utjehe filozofije i Erazmove Pohvale ludosti, uravnoteženom međusobnom kombinacijom, predstavljaju izvrstan paradigmatski okvir ispravne kvalitete življenja. Pritom se posebno misli na Boetijevu ozbiljnost pristupa životu i intelektualnu zauzetost u razumijevanju njegova pravoga smisla, te na Erazmov smisao za humor i sposobnost opuštenog mirenja s nesavršenošću i ograničenošću ljudskoga života. Međutim, prije nego li se pristupi detaljnijem obrazlaganju ove postavke, valja jasnije ukazati na određene vrjednote koje dvojica autora opisuju u svojim spisima.

\section{Boetije i Utjeha filozofije}

\subsection{Boetijev znanstveni $i$ društveno-politički život}

Boetije $^{3}$ je rođen u Rimu oko 480. godine, nedugo nakon konačnoga pada Zapadnoga Rimskog Carstva 476. godine, čija se destabilizacija, zbog brojnih neriješenih unutarnjih sukoba te urušavanja vanjskih granica pred navalom barbarskih naroda, počela događati i puno ranije. Upravo se ta godina uzima i kao godina završetka antičke kulture i civilizacije i početka srednjovjekovnoga razdoblja.

Kao obiteljski čovjek, društveno visoko pozicioniran i dobrostojeći, Boetije je imao aktivnu političku ulogu u Rimu. Istovremeno se je posvetio znanosti i filozofiji te je na latinski jezik prevodio djela velikih grčkih mislioca, obogaćujući ih svojim komentarima. Kasnije je slovio kao posljednji veliki filozof antike koji je svojim djelima uvelike pridonio srednjovjekovnomu upoznavanju s antičkom naukom jer su upravo njegova djela na određeni način povezivala antičku sa srednjovjekovnom tradicijom. ${ }^{4}$

U društveno-političkome životu odlikovala ga je pravednost i istančana etičnost, a što će ga na koncu koštati slobode i života. Naime, zauzimajući visoke položaje u društvu kao senator, kvestor, konzul pa čak i kao svojevrsni predsjednik vlade, odnosno magister officiorum, te pokazujući se istovremeno kao izrazito etična osoba, Boetije je s vremenom postajao brojnima omražen. To je bilo i uzrokom lažne optužbe protiv njega u kontekstu jedne političke intrige, zbog čega biva osuđen na smrt i zatočen u Paviji, odnosno današnjoj Pa- 
dovi gdje je, čekajući izvršenje smrtne kazne 524./525. godine, napisao svoju čuvenu Utjehu filozofije. Pritisnut nevoljom, a imajući u vidu svoj čestiti život i istančani osjećaj za pravdu i istinu, Boetije u tom djelu promišlja općenito o čovjeku, prirodi, Bogu, sreći i sudbini, kao i o istinskim i prividnim dobrima te o dobru i zlu. Drugim riječima, nastojao je na strogo filozofski način dosegnuti ono od čega se sastoji pravi smisao čovjekova života.

\subsection{Značajniji naglasci Utjehe filozofije}

Boetijeva Utjeha filozofije sastoji se od pet knjiga s ukupno trideset i osam poglavlja koja završavaju stihovima. Knjiga započinje opisom susreta Boetija $\mathrm{s}$ alegorijskim likom filozofije u obliku mlade žene, s kojom Boetije podijeli svoj smrtni strah:

»... opazih da mi ponad glave stoji žena vrlo dostojanstvenog izgleda: sjajnih i, izvan uobičajene ljudske moći, prodornih očiju; krepkog držanja i neiscrpne životne snage, mada je bila tako drevne dobi da se nikako ne bi mogla smatrati mojom vršnjakinjom (...)«.

Filozofija mu je došla u tamnicu kao pratnja nedužnomu na njegovu putu, pri čemu ga podsjeća na to kako su njezini poklonici redovito bili izlagani opasnostima ili su stradavali samo zato što su slijedili njezina etička načela. Boetije i sebe smatra poklonikom filozofije, ističući da se je cijeli svoj život rukovodio njezinim principima i kako se je upustio i u političke vode iz razloga što upravo filozofija zahtjeva da se mudri ljudi bave državničkim poslovima i u tome preteknu one loše. Boetijeva se tragedija ponajviše očituje u tome što su ga upravo ti loši ljudi, iako je časno izvršavao svoju državničku dužnost, optužili za izdaju i osudili na smrt. Odgovor je filozofije na Boetijevo jadikovanje u tom smislu kako se ništa ne događa slučajno, nego svime upravlja određena providnost. $^{6}$

Na haljini Boetijeve tješiteljice stoje dva ispisana grčka slova koja zapravo predstavljaju motiv čitave Utjehe filozofije. Na donjem rubu haljine stoji napisano grčko slovo $\pi$, a na gornjem slovo $\theta$, dok između ta dva slova vode ljestvene

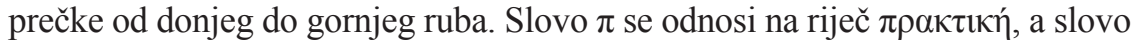
$\theta$ na $\theta \varepsilon \omega \rho \eta \tau \iota \kappa \eta,{ }^{7}$ što je Boetije prema tradicionalnoj podjeli prevodio s philosophia activa i philosophia speculativa. Tako se i cijeli razgovor uzdiže, kao po ljestvama, od aktivnoga zamršenog života prema čistim visinama spekulacije. ${ }^{8}$ Alegorija filozofije prije svega dijagnosticira stvarni Boetijev problem:

»Više ne znaš ono što si! «9

To ukazuje na činjenicu da je Boetijev problem spoznajne naravi, odnosno problem je nedostatak samospoznaje. Osim toga, Boetiju dodatno stvari kom-

Opširan prikaz Boetijeva života i djela, kao i povijesnih te društveno-političkih prilika u Zapadnom Rimskom Carstvu do njegova konačna propadanja, donosi Marko Višić, »Boetije, život i djelo«, u: Boetije, Utjeha filosofije, ITP »Unireks«, Podgorica 2008. str. 9-48.

4

Usp. Snježana Tomašević, »Boetie - Utjeha filozofije«. Dostupno na: http://nova-akropola.hr/kultura/filozofija-znamenite-licnostiBoetiju (pristupljeno 31. 8. 2015.).
6

Ibid., I, III, 20 i dalje.

Ibid., I, I, 16-21.

8

Usp. Marie Luise Gothein, »Nachwort Trost der Philosophie«, u: Anicius Manlius Severinus Boethius, Trost der Philosophie, Berlin, 1932. Dostupno na: https://www.unifr.ch/bkv/ kapitel5131.htm (pristupljeno 25. 9. 2015.).

9

Boetije, Utjeha filozofije, I, VI, 40. 
plicira i što je zaboravio svrhu ili cilj stvari, kao i načine upravljanja svijetom. ${ }^{10}$ Ponovno otkrivanje moći rasuđivanja označava i svojevrsno filozofsko buđenje i svladavanje letargije kao opće bolesti misaonog zavaravanja. ${ }^{11}$

Filozofija upućuje Boetija prema razumijevanju istinske sreće, fortune, koja se ne nalazi u izvanjskim i prolaznim stvarima, nego u njemu samome. Dovodi ga do svijesti o prolaznosti i iluzornosti nekih lažnih dobara, kao što su bogatstvo, moć, slava, visoki položaj i tjelesne naslade, te Boetije konačno uspijeva reflektirati nad većim dobrom ili srećom kojom se postiže božanstvo:

»Svaki sretan čovjek je Bog, mada u stvari postoji samo jedan Bog; ništa uistinu ne priječi da ih dijeljenjem bude koliko nam je drago. ${ }^{12}$

Upravo je i problem zla u svijetu uzrokovan neznanjem koje slabe ljude upućuje na traženje lažnih dobara. Svjesnom i slobodnom odlukom za takvo postupanje ljudska bića gube svoju narav i, pretvarajući se u čudovišta, prestaju biti ljudi. ${ }^{13}$ Nasuprot tomu, težnja dobrih ljudi prema božanskomu vodi $\mathrm{k}$ istinskoj sreći i slobodi od zamke sudbine, a ova postaje utoliko veća ukoliko se više kontemplira božanski um. Najavljivano Boetijevo ozdravljenje se sada konačno predstavlja ne samo kao prijelaz s krivoga mišljenja prema istini nego i kao jačanje izgubljene slobode. Na koncu filozofija završava svoj nagovor pozivajući ljude da se nadaju i mole za život ispunjen težnjom za božanskim. ${ }^{14}$

Ono što iz cjelokupne Boetijeve Utjehe filozofije, ovdje sažeto prikazane, postaje sasvim evidentno jest činjenica da on nije ponudio neko jednostavno i brzo rješenje životnih problema, nego je pomoću imaginarnoga vodstva alegorijskog lika filozofije ukazao na potrebu ozbiljnosti i intelektualne ustrajnosti na putu samospoznaje i jasnijeg razumijevanja stvari oko i iznad sebe. Takvo nastojanje je najbolji način dolaženja do svijesti o potrebi jasnog razlikovanja prividnih i lažnih od stvarnih i istinitih dobara, kao i pronalaženja istinske sreće i ostvarivanja ispravnoga življenja, a što je već po sebi najveća nagrada koju čovjek dodjeljuje samomu sebi.

\section{Erazmo Roterdamski i Pohvala ludosti}

\subsection{Erazmo i novi duh vremena}

Za razliku od Boetija i njegova života na razmeđi antičke i srednjovjekovne civilizacije, Erazmo Roterdamski tisuću godina kasnije isto tako svjedoči prekidu srednjega vijeka i rađanju jedne nove epohe, renesanse. Punim imenom Desiderius Erasmus Roterodamus, rođen je 1466. godine kao vanbračno dijete jednoga svećenika što će, uz ranu smrt oba roditelja i nedostatak obiteljske nježnosti, na njega ostaviti i određene psihološke posljedice. Kao vrlo mlad, pod do kraja nejasnim motivima takva odabira, Erazmo stupa u augustinski samostan gdje kroz pet godina izbliza upoznaje »sva ograničenja tradicionalnoga kršćanskog nauka«. ${ }^{15}$ Iako nikad nije požalio što je 1492 . godine zaređen za svećenika, Erazmo kao tajnik biskupa iz Cambraija biva izuzet iz propisa samostanskoga života i postaje slobodan svećenik, upravo kako je i odgovaralo potrebama njegova duha. ${ }^{16}$ Nakon toga su uslijedila njegova brojna putovanja diljem humanističke Europe, vođena žarkom željom predanoga izučavanja antičkih pisaca i klasične literature.

Društveno-povijesni i kulturološki kontekst Erazmova vremena, obilježen rađanjem jedne nove epohe, bitno je utjecao i na stanje njegova duha, pa je u teološkim i ideološkim sukobima svojega vremena neprestance osjećao 
rastrganost između očuvanja staroga i potrebe za stvaranjem nečega novoga. On nije više bio čovjek srednjovjekovnoga duha pa je i njegova misao slobodnija i okrenuta svijetu, što će mu nerijetko priskrbiti brojne poteškoće i nerazumijevanja. Valja spomenuti da Erazmo nije pisao strogo filozofske knjige, ali je svojom velikom humanističkom kulturom i svojim širokim utjecajem imao odlučnu riječ u borbi za nadilaženje starih i otvaranje novih pogleda na svijet. Jednostavno rečeno, Erazmo je u svojim djelima odražavao duh svoga vremena.

Kao crkveni čovjek i teolog predstavljao se žestokim kritičarem svakoga oblika prijetvornosti i isključivosti, te zagovornikom religioznosti utemeljene na izvornoj evanđeoskoj poruci ili Kristovoj filozofiji. ${ }^{17}$ Odlučno je ustajao protiv zatiranja ljudskih vrijednosti i ograničavanja zdravoga razuma. U duhu svoga vremena i osjećanja htio je i na crkvenom području provesti društvenokritičku promjenu pa su, i u tom smislu, brojni napadi na njega nešto što je bilo posve očekivano.

Erazmo je posebno ostao poznat po svojem satiričkom spisu Pohvala ludosti, koji mu je osigurao veliku i trajnu slavu. Iako je taj spis u ono vrijeme odmah bio stavljen u popis strogo zabranjenih $\mathrm{knjiga},{ }^{18}$ preveden je na brojne jezike i bio čitan posvuda, nailazeći kako na brojne pohvale tako i na žestoke kritike i osude. ${ }^{19}$ Iako za vrijeme pisanja Pohvale ludosti Erazmo nije, poput Boetija za vrijeme pisanja Utjehe filozofije, bio u smrtnome strahu, valja imati u vidu da ga je, gore već spomenuta, rastrganost duha između vrijednosti staroga i izazova novoga zasigurno pratila i pri stvaranju ovoga djela. Erazmo je u njega unio čitavoga sebe, odnosno »svu svoju znanost i svu svoju umjetnost,

10

Ibid., I, VI, 44-46.

11

Usp. Thérèse-Anne Druart, »Philosophical Consolation in Christianity and Islam: Boethius and al Kindi«, Topoi - An International Review of Philosophy 19 (1/2000), str. 25-34, str. 27. doi: https://doi.org/10.1023/ a: 1006395306822 .

12

Boetije, Utjeha filozofije, III, X, 88-90.

13

Ibid., IV, III, 66-68.

14

Ibid., V, VI, 171-176.

15

Zvonimir Milanović, »Predgovor«, u: Erazmo Roterdamski, Pohvala ludosti, Cid-Nova, Zagreb 1999., str. 1-10., str. 3.

16

Usp. L. Halkin, Erazmo i kršćanski humanizam, str. 41.

17

Pojam Kristove filozofije u Erazmovim spisima ima središnje mjesto, a pod njime podrazumijeva svojevrsnu sintezu teologije i duhovnosti. Riječ je o sustavu usklađenih vrijednosti, pa u tom smislu i o filozofiji, ali filozofiji koja nije ljudska i strogo intelektual- na, nego je više božanska $\mathrm{i}$ jednako pristupačna svima, o filozofiji koja je mudrost i život. Više o Erazmovu shvaćanju Kristove filozofije usp. ibid., str. 143. i dalje.

18

Osim ove knjige i druga su djela ovog nizozemskog humanista već 1559 . godine stavljena na indeks zabranjenih knjiga od strane španjolske inkvizicije, a Pohvala ludosti tek je osam godina nakon definitivnog gašenja inkvizicije 1842. godine tiskana $\mathrm{i}$ na španjolskom jeziku. Vidi »Erste spanische Übersetzung von Erasmus' «Lob der Torheit» entdeckt«, Universität Basel 2012. Dostupno na: https://www.unibas.ch/de/Aktuell/News/ Uni-Research/Erste-spanische--bersetzungvon-Erasmus---Lob-der-Torheit--entdeckt. html (pristupljeno 25. 9. 2016.).

19

Nezadovoljstvo koje je njegova Pohvala ludosti izazvala pronalazi svoj eho još i danas. Tako švicarski teolog Walter Nigg primjećuje kako se, unatoč svom humanističkom okviru, radi o jednoj od najopasnijih knjiga svjetske literature, koja je uzrokovala svjetsko vrenje u zapadnjačkom duhovnom životu. Usp. Hektor Haarkötter, » Die Torheit ging, die Idioten blieben«, Telepolis 2012. Dostupno na: https:// www.heise.de/tp/features/Die-Torheit-gingdie-Idioten-blieben-3392581.html (pristupljeno 23. 9. 2016.). 
svu svoju kritiku i svu svoju vjeru« ${ }^{20}$ Za to djelo Erazmo je dobivao najveća priznanja i sve se više pokazivao predvodnikom humanističkoga duha i autoritetom svojega vremena.

\subsection{Značajniji naglasci Pohvale ludosti ${ }^{21}$}

Metodološki slično Boetiju i njegovu personificiranom liku filozofije i Erazmo personificira lik ludosti i dopušta joj izlaganje svojih ideja s velikom rječitošću i mnogo humora. Ono što ih u ovom kontekstu razlikuje jest činjenica da se u Boetijevu spisu radi o dijalogu između samoga Boetija i personificiranog lika filozofije, a u Erazmovu o monologu kojega vodi personificirani lik ludosti. Temeljna je misao izlaganja ludosti ona o tome kako joj zapravo velika većina, ako ne i sve ljudske djelatnosti, trebaju u potpunosti biti zahvalne jer je u sve upletena.

U Erazmovoj satiri, istina, puno je toga ironično mišljeno, ali je riječ i o navlastito prijateljskome načinu ironije koja ne predstavlja samo neko jednostavno izvrtanje određene riječi ili izreke u njezinu suprotnost. Personificirana ludost, pored stavova koji nastaju u izokretanju prihvaćene točke gledišta, zastupa i stavove koji bi se i s Erazmovom i s mišlju njegovih čitalaca čak smjeli u potpunosti i podudarati. Nerijetko se, naime, kroz lik ludosti posve ozbiljno razmatraju određena teološka i moralna pitanja, pri čemu zapravo Erazmo izlaŽe vlastite stavove. Njegova ludost na taj način predstavlja ujedno simpatičnu i paradoksalno mudru personifikaciju koja uspijeva sasvim jasno $i$ argumentirati svoje stavove. Posljedica toga je izrazita snaga uvjeravanja koja lako može dovesti do zaključka da je sama ludost u konačnici nešto dobro za čovjeka. Umjesto karakternog svojstva vrijedna prezira, ona se pokazuje poželjnom kardinalnom vrlinom. To će se, pak, na koncu cjelokupnog izlaganja personificirane ludosti i na koncu samoga djela opet namjerno dovesti u pitanje, to jest kada Erazmo dopušta ludosti da u trajno nerazumnoj maniri završi:

$»$ Vidim da očekujete epilog, ali ste stvarno poludjeli ako uistinu mislite da se ja još uvijek sjećam svega što sam rekla kada sam toliku hrpu riječi istresla. $\ll^{22}$

Ovakvo dvojako razumijevanje ludosti, odnosno dva Erazmova pristupa razmatranju stvari, međusobno se isprepliću, iako u većoj mjeri prevladava onaj duhoviti prizvuk. Kako je već naznačeno, takav dvojaki pristup je u velikoj mjeri bila i posljedica stanja Erazmova duha. ${ }^{23}$

Prava nakana njegova satiričnog teksta nije u isticanju ludosti ludih, nego daleko više ludosti mudrih ili onih koji se takvima smatraju. Spis se osobito usmjerava protiv licemjerstva crkvenih velikodostojanstvenika te umišljenosti i iskustvene udaljenosti znanstvenika. $U$ tom se smislu brzo pokazuje da ludost nije »kod kuće«, tako reći, samo kod onih ljudi kod kojih bi se to i naslućivalo, naime kod onih kojima nedostaje životnoga iskustva, obrazovanja, vjere ili racionalne samokontrole, nego isto tako, i naročito, kod onih koji isključivo vlastito znanje i mudrost uzimaju kao jedino relevantne. U konačnici su upravo navodni protivnici ludosti oni koji se sami gube u beskonačnim sitničavostima i pojmovnim cjepidlačenjima. ${ }^{24}$

Znakom ludosti je, prema Erazmu, da se na neka pitanja ne zna prave odgovore, ali daleko veća ludost jest ni na što ostati dužan odgovoriti. Pritom je riječ o ludosti kao izrazu neumjerenoga precjenjivanja vlastitih sposobnosti. Kao konačno biće i u konačnome svijetu čovjek je bez pristupa vječnim istinama, a na koje se, posebice teolozi i filozofi, uvijek rado zaklinju. Čovjek živi u neznanju, pa čak i prirodna znanost zahvaća samo gornje slojeve stvari. I svijet i čovjek sami sebi jesu i ostaju zagonetkom. Opaska o tome kako ludost 
čovjeka zapravo drži u zabludi i neznanju za neke se može činiti bijednom, ali Erazmova ludost, naprotiv, to baš i smatra pravim načinom bivanja čovjekom. ${ }^{25}$ Ovakvo stajalište zasigurno otvara brojna nova pitanja i za samu antropologiju jer na svoj način problematizira općeprihvaćenu filozofsku tradiciju o čovjeku kao animal rationale. ${ }^{26}$

Sažeto se može zaključiti da Erazmo u svojoj Pohvali ludosti, izražavajući na umjetnički način najdublje istine o životu i pružajući najkritičniji sud o njegovim pojavama, ismijava sve tadašnje uvriježene običaje i ugledne ličnosti ljudskoga društva, ozbiljno hvaleći ludost kao samosvijest o vlastitoj ograničenosti i nemogućnosti sveznanja.

\section{Vrijednosni postulati dvaju spisa kao paradigmatski okvir kvalitete življenja}

\subsection{Boetijevska ozbiljnost pristupa životu i intelektualna predanost u razumijevanju stvari}

Nakon ukazivanja na neke glavne naglaske dvojice autora i njihovih djela, u nastavku se teksta želi ukazati na činjenicu da uvažavanje i prihvaćanje njihovih vrijednosnih postulata općenito predstavlja dobar paradigmatski okvir kvalitete življenja.

Razmatrajući Boetijevu Utjehu filozofije, koja već po svom naslovu pripada tradiciji antičke utješne literature s ciljem oslobađanja od duševne boli i žalosti te postizanjem mira i zadovoljstva unatoč nesreći, djelo se pokazuje kao dubokoumna i ozbiljna filozofska rasprava temeljnih egzistencijalnih pitanja. ${ }^{27}$ S obzirom na Boetijevu ozbiljnost pristupa ovim temeljnim filozofskim pita-

20

Usp. L.-E. Halkin, Erazmo i kršćanski humanizam, str. 67.

21

Erazmo je izvorno ovo djelo napisao za čisto osobnu uporabu 1509. godine, a obavljeno je 1511. godine, te ga je uz vlastitu poslanicu posvetio engleskom prijatelju Thomasu Moreu. Izvorni grčki naslov knjige glasio je Enkomium Moriae, a slučajna sličnost grčke riječi za ludost (moria) i prezimena njegova prijatelja navodno je Erazmu uopće i dala ideju. Usp. H. Haarkötter, »Die Torheit ging, die Idioten blieben«.

22

E. Roterdamski, Pohvala ludosti, str. 168.

23

Iako kao jedan od pripravitelja reformacije, činjenica je da je Erazmo održao vjernost papi i da je njegovo izdanje Novoga zavjeta na starogrčkom jeziku poslužilo Martinu Lutheru u prijevodu Svetoga pisma na njemački. Istovremeno je Erazmo bio možda i najžešće kritiziran upravo od Luthera, a svojevrsno ispravljanje te pogreške neki autori vide u činjenici da je Erazmo jedini od katoličkih svećenika koji je pokopan u nekoj protestantskoj crkvi, naime u Baselu u Švicarskoj. Usp. H. Haarkötter, »Die Torheit ging, die Idioten blieben«.
24

Erazmo se u ovom kontekstu, kao i na mnogim drugim mjestima, na poseban način kritički odnosi prema ondašnjim teolozima, usp. str. 109.-117. i str. 150. On isto tako često kritizira i filozofe svojega vremena, konstatirajući za njih da time što o pojedinim stvarima vode vječite prepirke dovoljno dokazuju da zapravo ne razumiju ništa od onoga o čemu pričaju. Usp. E. Roterdamski, Pohvala ludosti, str. 107-108.

25

Usp. Ibid, str. 64.

26

Usp. Michael Hauskeller, »Lob der Torheit. Über das Wunderbare, die Philosophie und die Liebe«, u: Michael Hauskeller (ur.), Auf der Suche nach dem Guten, Die Graue Editions, Zug 1999., str. 13-31.

27

Usp. Ivan Bubalo, »Boetije i Filozofija«, Filozofska istraživanja 10 (4/1990), str. 11411156, str. 1143. Ivan Bubalo u svojem tekstu kao zanimljivost ističe i činjenicu da Boetije kao kršćanin, koji se u svojim teološkim tekstovima zauzimao za stvar crkvenoga pravovjerja, našavši se in extremis nije tražio utjehu niti u vjeri niti u teologiji, nego baš u filozofiji, i to na takav način da se po samome djelu nikako ne bi mogao prepoznati kršćanski autor. Vidi ibid., str. 1153. 
njima, može se reći da on nije bio samo vrsni poznavalac filozofije i filozof u pravom smislu te riječi nego je očito filozofija predstavljala čitav njegov život, ona mu je bila životno opredjeljenje. ${ }^{28}$ Naravno da su toj ozbiljnosti pristupa temeljnim egzistencijalnim pitanjima u velikoj mjeri dodatno pridonijele i nezahvalne okolnosti u kojima se Boetije našao, odnosno susret s iznenadnom i neželjenom smrću. Kada se tomu doda i činjenica objektivne neutemeljenosti za to, uzrokovane nepravednom osudom, sama po sebi se pokazuje sva težina situacije u kojoj se Boetije nalazio i koju je, unatoč svemu, nastojao rasvijetliti svojim umom i zahtjevnim intelektualnim naporom. Upravo takvo nastojanje i ozbiljnost pristupa životu u svim njegovim situacijama valja istaknuti kao snažne vrijednosne postulate Boetijeve Utjehe filozofije. Uz temeljnu poruku ovoga djela - da se ne treba niti zamarati prolaznim stvarima niti um zarobiti strastima, nego razvijati svoju slobodu i sposobnost uzdizanja k uzvišenijim stvarima - njegovu se čitatelju sama po sebi nameće i važnost ozbiljnoga i odgovornoga suočavanja s konkretnim životnim situacijama ma koliko one bile komplicirane ili se činile bezizglednima. U svemu tome pripomoć filozofije kao intelektualnog dosezanja smisla te razvoja sposobnosti dubokoumnog promišljanja svakako je neupitna. ${ }^{29}$

Dakle, ako se i zanemari činjenica da i danas postoji određeni broj autora koji filozofiju promatraju u svjetlu njezine uloge životnoga puta i svojevrsne medicine koja može pozitivno utjecati na čovjekovo duševno stanje, ${ }^{30}$ Boetijeva Utjeha filozofije potvrđuje da ozbiljan i odgovoran pristup životu, te slobodno podvrgavanje uzvišenoj službi promišljanja i kontemplacije nad njim, nužno pridonosi kvaliteti življenja.

To je ujedno i pravi način upoznavanja samoga sebe, od čega je filozofija i krenula, dijagnosticirajući Boetijev stvarni uzrok problema. Riječ je o svojevrsnom bdijenju nad samim sobom i temeljnom principu koji se izražava u uobičajenom zahtjevu »upoznaj samoga sebe«, koji je bio postavljen na stupu Apolonova hrama u Delfima. Taj princip protiv samozaboravljivosti, kao i princip potrebe razumijevanja stvari i događaja općenito, povlači se sve do u moderno vrijeme u kojem se kao primjer nameće ono što je Hannah Arendt (1906.-1975.) imenovala odlučujućim motivom vlastitoga mišljenja:

»Želim razumjeti ${ }^{31}$

Boetijev se poučak može sažeti na slijedeći način: Želja za razumijevanjem stvari, za osiguranjem u životu i svim njegovim situacijama umnoga rasvjetljavanja, vrijednosni je postulat koji prije svega proizlazi iz same ljudske naravi i koji kao takav nužno pridonosi kvaliteti življenja. Želja za razumijevanjem štiti od samozaboravljivosti koja predstavlja početak bolesti jadikovanja i prepuštanja sudbinskom elementu bačenosti i nemogućnosti bilo kakva djelovanja u suprotnom pravcu. Ovaj Boetijev poučak predstavlja bitni dio paradigmatskoga okvira kvalitete življenja koji, zbog ograničenosti ljudskih mogućnosti općenito, a samim tim i njegovih kognitivnih sposobnosti, zahtjeva i onaj drugi dio, odnosno sposobnost opuštenijega pristupa u razumijevanju različitih životnih situacija. Dok se onaj prvi dio može okarakterizirati kao boetijevski, ovaj drugi u tom se smislu može smatrati erazmovskim.

\subsection{Erazmovski smisao za humor i opušteno mirenje s vlastitom nesavršenošću}

Za razliku od Boetija, a sasvim sigurno i na temelju različitih životnih okolnosti i ogromne vremenske distance, Erazmo Roterdamski je došao do spoznaje da je čovjek slab i nesavršen, njegovo djelovanje često apsurdno i nerazumlji- 
vo, prožeto strašću, te prepredenom lukavštinom i humorom. Naizgled su sve to elementi koji mogu odati dojam očaja ili rezignacije zbog istine o sebi, što je uvijek najbolji način olakog mirenja sa životnom sudbinom. Međutim, za Erazma je ta spoznaja, utemeljena na očiglednim činjenicama, razlog da se ljudska nesavršenost ne proklinje, nego štoviše da se pohvaljuje. Dakle, kao jedan od prvih mislilaca novoga doba, Erazmo izdiže ludost i »budalaštinu« na pijedestal nužnoga dobra. U tome se sastoji i filozofska vrijednost ovoga djela, naime u činjenici da Erazmo ludost ne promatra samo kao opačinu vrijednu prezira nego i kao nužnu obmanu koja ljudsko postojanje uopće tek i čini izdržljivim, koja život tek čini vrijednim življenja. Ludost, kao ona koja po svojoj naravi ima više lica, ako i jest odgovorna za ljudske pogreške, isto tako i pomaže ljudima živjeti jer predstavlja skrivenu riznicu života, životne spontanosti i njegove raspoloživosti. ${ }^{32}$ Stoga se za Erazma istinska mudrost sastoji od spoznaje vlastite ograničenosti i opuštenog mirenja s iluzornim karakterom života: tek je ludost prava mudrost, a umišljena mudrost jest ludost. $^{33}$

$\mathrm{Na}$ koncu se može ustvrditi kako elementi poput perspektive naivne lude, ironični pogled na postojeće društvene vrijednosti i norme, kao i položaj ludosti na mjestu nužnoga dobra, u velikoj mjeri konvergiraju sa Sokratovim principom »znam da ništa ne znam « $\mathrm{i}$ činjenicom da istina nikada nije sasvim očigledna i nadohvat ruke. Ovaj princip po sebi vodi poniznosti, pogotovo kada se radi o razumijevanju najdubljih tajni ljudske naravi i uopće osnova ljudskoga znanja i ljudske mudrosti. ${ }^{34}$ On potiče na prihvaćanje vlastitih nesavršenosti te kognitivnih i svih drugih ograničenosti kao zapravo najboljega načina napredovanja u spoznajnom procesu, a što onda istovremeno upućuje na činjenicu kako takav pristup životu značajno pridonosi kvaliteti življenja.

28

Ibid. str. 1155.

29

Kada je riječ o samoj filozofiji i mogućnostima njezine utjehe, posebice u problematičnim životnim situacijama, valja napomenuti da se o tome dosta raspravljalo među filozofima. Izvorište je takvih rasprava općenito u razumijevanju filozofije, je li ona jednostavno teorija ili kontemplacija ili je prvenstveno životni put. Na opravdanost pitanja određenoga koncepta filozofije zasigurno ukazuje i Boetijevo djelo. Usp. T. Druart, »Philosophical Consolation in Christianity and Islam: Boethius and al Kindi«, str. 25.

30

Činjenica je da je zahtjev za praktičnošću filozofije toliko star koliko i sama filozofija te da su već grčki filozofi naučavali da čovjek potrebuje fillozofskog poučavanja da bi sa svojim iskustvima u svijetu mogao izlaziti na kraj. Iz te se činjenica onda izvodio zaključak da je zadaća filozofije i u tome da nastupa kao therapeia, da radi na izgrađivanju ljudskih duša, da ljude prati kod oblikovanja vlastitoga života i napose u graničnim životnim situacijama. Danas je poznata takozvana filozofska praksa zajedničkoga dijaloškog promišljanja koje nastoji da se kroz predmet razgovora dođe do »priopćavanja egzistencije« i do prosvjećenosti. U Njemačkoj trenutno postoji oko 130 filozofskih praksi u kojima filozofi svoje znanje stavljaju u službu drugima da bi im se pružila podrška u svladavanju njihovih problema. Opširnije o filozofskoj praksi više u B. Ehrenberg, »Mit dem Philosophen auf der Couch $\ll$.

3

Usp. Ursula Ludz (ur.), Hannah Arendt - Ich will verstehen. Selbstauskünfte zu Leben und Werk, Piper Verlag, München 2005.

32

L. Halkin, Erazmo i kršćanski humanizam, str. 64.

33

Usp. Kurt Steinmann, »Nachwort«, iz: Erasmus von Rotterdam, Das Lob der Torheit. Dostupno na: http://www.kultur-fibel.de/Ku ltur $\% 20$ Fibel, \%20Buch, \%20Erasmus\%20BTitel.html (pristupljeno 20. 1. 2016.).

34

O Sokratovu »neznanju« i njegovoj majeutičkoj metodi, koja se sastoji u iznuđivanju općeg iskaza i pokazivanja njegove manjkavosti kroz raspravu koja potom slijedi, više u: William Keith Chambers Guthrie, Povijest grčke filozofije. Sofisti-Sokrat, Naklada Jurčić, Zagreb 2006., str. 426-432. 
Sve skupa ukazuje na jednostavan zaključak da su oba principa, odnosno onaj boetijevski i ovaj erazmovski, jednako vrijedni i upravo poželjni za kvalitetan život i lakše ophođenje sa svim njegovim situacijama. Kao ograničeno i nesavršeno biće čovjek nije u stanju niti sve moći razumjeti niti sve spoznati, koliko se god u tome iskreno trudio i to žarko želio. Ne priznavati sebi takvu ograničenost označavalo bi istinsku ludost, a opterećivati se zbog nje samo prividnost života. Isto tako, pomiriti se olako s vlastitom ograničenošću, bez želje za pokušajem razumijevanja i iskrene predanosti u tome, predstavlja još veću ludost te, jednako tako, tek prividno življenje. Boetije i Erazmo u svojim spisima pokazuju kako upravo spomenuta predanost istinskom razumijevanju stvari vodi prema takvoj vrsti ljudske slobode, koja je i jedina kadra opušteno prihvatiti vlastite nesavršenosti; to je istinska mudrost i prema jednom i prema drugom autoru.

\section{Zaključne misli}

Primjer Boetija prije svega pokazuje koliko može biti visoka cijena života koji se živi protivno principima samo prividnoga izgleda pravednika a u skladu s onima stvarnoga, o čemu je već Platon promišljao u svojoj Državi. ${ }^{35}$ Paradoksalna situacija u kojoj se našao, gdje mu, unatoč izrazito istančanoga osjećaja za pravednost i etičnost u ponašanju i djelovanju slijedi neutemeljena smrtna kazna, potakla ga je na intenzivno samopropitivanje o istinskim vrijednostima i pravom smislu života. Nije se olako prepustio sudbini, iako se u prvi mah čini da mu drugo niti ne preostaje, nego je poduzeo ono što je u tom trenutku jedino i mogao učiniti - nastojao je razumjeti zašto mu se događa to što se događa. U toj želji i nastojanju da razumije, prvenstveno je došao do istinske samospoznaje, a što mu je onda otvorilo i nove horizonte u jasnijem sagledavanju stvari oko sebe i iznad sebe. Pritom uviđa da život u skladu s etičkim načelima, kako ga je i sam živio, bez obzira na tragičan završetak nije bio promašen život, te da se tek u svijetlu sveukupnosti zbilje očituje njegova prava veličina i značaj, kao i sva prividnost nekih ovozemaljskih dobara.

Do vrlo sličnih spoznaja, samo na drugačiji način, dolazi i Erazmo Roterdamski u svojoj Pohvali ludosti, kada kao žestoki kritičar svakog oblika prijetvornosti ili hipokrizije s velikom dozom ironije gleda na sve ono što su ljudi nametnuli kao opće vrijedeće običaje i zakonitosti ponašanja i djelovanja, kao i na uglednike koji svoje sposobnosti i znanja uzimaju jedino relevantnima. Uviđajući te ljudske sklonosti, on na izrazito satiričan način hvali ludost kao nužnu obmanu koja olakšava ljudima njihovo življenje, razlikujući pritom mudru ludost kao svijest o vlastitoj nesavršenosti od prave ludosti kao posljedice izrazito umišljene mudrosti.

Iz spisa se dvojice autora jasno pokazuje da su sposobnost kontemplacije, intelektualnoga napora i želje za razumijevanjem usko povezani sa sposobnošću opuštenog mirenja s vlastitom nesavršenošću i neopterećenošću, napose beznačajnim stvarima. Jedno bez drugoga je teško zamislivo, inače bi se radilo doista o pravoj ludosti. Sposobnost lakog mirenja s vlastitim ograničenostima i iluzornim karakterom života svoj pravi smisao zadobiva upravo utoliko, ukoliko joj je prethodilo zauzeto nastojanje u pokušaju razumijevanja stvari i događaja. Tek tada ono u pravom smislu predstavlja poželjnu i oslobađajuću vrlinu, odnosno nešto što pridonosi kvaliteti življenja. Bez intelektualnog napora i pokušaja razumijevanja stvari, teško je prispjeti takvoj slobodi. U tome se očituje međusobna uvjetovanost i prožetost sposobnosti ozbiljnosti pristupa stvarima i neopterećivanja onim beznačajnima, intelektualne zauzetosti 
i opuštenoga mirenja s ljudskom nesavršenošću. Uvažavanje svih tih vrijednosnih postulata, koji se jasno iščitavaju iz spisa ovdje razmatranih autora, te njihova uravnotežena kombinacija i integracija u vlastiti život, predstavlja pravu paradigmu kvalitetno i mudro osmišljenoga života.

\section{Ivo Džinić}

Trost der Philosophie und Lob der Torheit: Der paradigmatische Rahmen der Lebensqualität

\section{Zusammenfassung}

Im Hintergrund dieses Artikels stehen zwei Schriften, die mit ihrer Einfachheit aber auch Denktiefe den paradigmatischen Rahmen für die echte Lebensqualität darstellen. Es geht um Boethius '(480-525) Trost der Philosophie und um Erasmus'(1465-1536) Lob der Torheit. Durch das ernsthafte philosophische Denken und die intelektuelle Anstrengung wies Boethius hin, dass der eigentliche Sinn und Wert des menschlichen Lebens auf der Lebensverantwortung und seiner Ethik beruht. Andererseits zieht Erasmus in seinem satirischen Nachdenken über die Torheit die Folgerung, dass die echte Weisheit erst in der Erkenntnis der eigenen Beschränkteit und in der gelassenen Versöhnung mit dem illusionären Charakter des Lebens besteht.

Mit diesem Artikel wird es versucht zu zeigen, dass die ausgeglichene Kombination der Wertpostulate aus diesen zwei Schriften ein gutes Paradigma für Lebensqualität darstellt.

\section{Schlüsselwörter}

Boethius, Erasmus von Rotterdam, Trost der Philosophie, Lob der Torheit, Wertpostulate, Lebensqualität

Platon je o ovom pitanju raspravljao u drugoj knjizi svoje Države, ukazujući na ontološku razliku između istinskoga bitka i varljivoga pričina, čime je postavio nove temelje svojoj etici i spoznajnoj teoriji. Pritom je ukazao i na veliku ulogu filozofije u razotkrivanju prave razlike između prividno stvorenoga dojma i savršenosti etičkih normi kao onih kojih se treba pridržavati u svakodnevnome životu. Usp. Platon, Država, Naklada Jurčić, Zagreb 2001., 362a i dalje. 